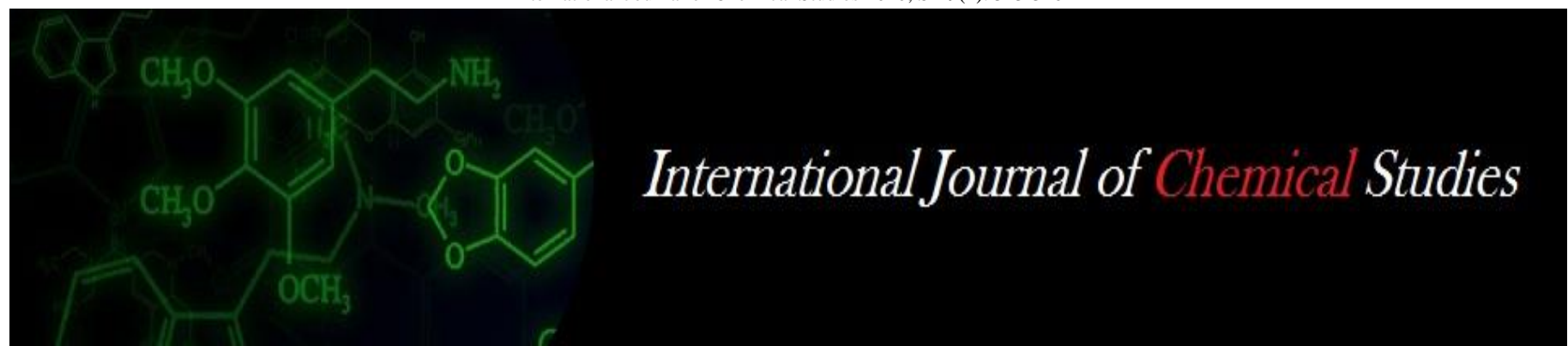

P-ISSN: 2349-8528

E-ISSN: 2321-4902

www.chemijournal.com

IJCS 2021; SP-9(1): 323-326

(C) 2021 IJCS

Received: 15-11-2020

Accepted: 23-12-2020

ER Nakum Divyangkumar Department of Renewable Energy Engineering, CTAE, MPUAT, Udaipur, Rajasthan, India

\section{Dr. Sudhir Jain}

Professor and HoD, Department of Renewable Energy

Engineering, CTAE, MPUAT,

Udaipur, Rajasthan, India

\section{Techno-economic feasibility of the latent heat storage material to use in a solar tunnel dryer}

\author{
ER Nakum Divyangkumar and Dr. Sudhir Jain
}

DOI: https://doi.org/10.22271/chemi.2021.v9.i1f.11782

\begin{abstract}
For efficient utilization of freely available solar energy for drying of Potato Slices (Solanum tuberosum) experiment has been carried out keeping in view to extend drying hours with efficient Latent heat storage material system was designed and installed at Department of Renewable Energy Engineering, CTAE, MPUAT, Udaipur. Techno- Economic analysis of the PCM (Phase Change Material) integrated with the unit carried out to supply the heat to the tunnel dryer. Barioum hydroxide octahydrate [Ba(oh)2 8h2o] was used as a heat storage material. It is concluded that the heat sink unit with heat storage material enables to maintain constant air temperature inside the dryer and heat stored in phase change material in heat exchanger during day time can be utilized during non-sunshine hours because of which drying time could be extended up to 4 hours. The Net Present Worth of the heat sink unit is 123785.98 ₹ with a 1.33 , 1.268 years and $62 \%$ are the benefit-cost ratio, payback period and Internal Rate of Return (IRR), respectively. Considering the initial cost of the heat storage material is $60 \mathrm{Rs} / \mathrm{kg}$ with the 1000 life cycle. Based on economic analysis, it was concluded that investment on the heat storage material for solar tunnel dryer is justified.
\end{abstract}

Keywords: PCM, Heat storage material, drying, techno-economic

\section{Introduction}

The drying process is one of the most important application to utilize solar energy. It is a traditional method of food preservation, which provides longer shelf life, lighter weight for transportation and small space for storage ${ }^{[1]}$. It consists of a significant part of the world's energy (about 30\%) is spent on the agricultural sector and about $3.62 \%$ used for drying of agricultural products ${ }^{[2]}$ There are several drying technologies such as hot air drying, spray drying, vacuum drying, freeze-drying, microwave drying for the production of dried powders from food ${ }^{[3]}$.

The drying process is largely dependent on weather conditions and is very difficult during the rainy season. Solar dryers work only on day time when optimum solar radiation is available, but when inadequate solar radiation is available as the solar radiation is intermittent in nature, in that case, solar dryer does not work properly. Some products need more time for drying in a tunnel dryer but the sunshine available in the day time is about 8 hours. So the process of drying breaks and it will have to continue the next day when sunrise and adequate solar radiation available. Due to this unevenness in the drying process product quality gets badly affected. However, in the night time process being reversed and product will start to gain moisture from the atmosphere.

To overcome this, it is required to attach Thermal Energy Storage (TES) devices with solar gadgets. The stored energy can be utilized during off sunshine hours or under peak load conditions ${ }^{[4]}$. Thermal energy processes are done under three-stage (charging, storing, and discharging). Three kinds of TES systems are available as shown in Fig 1. ${ }^{[5]}$. 


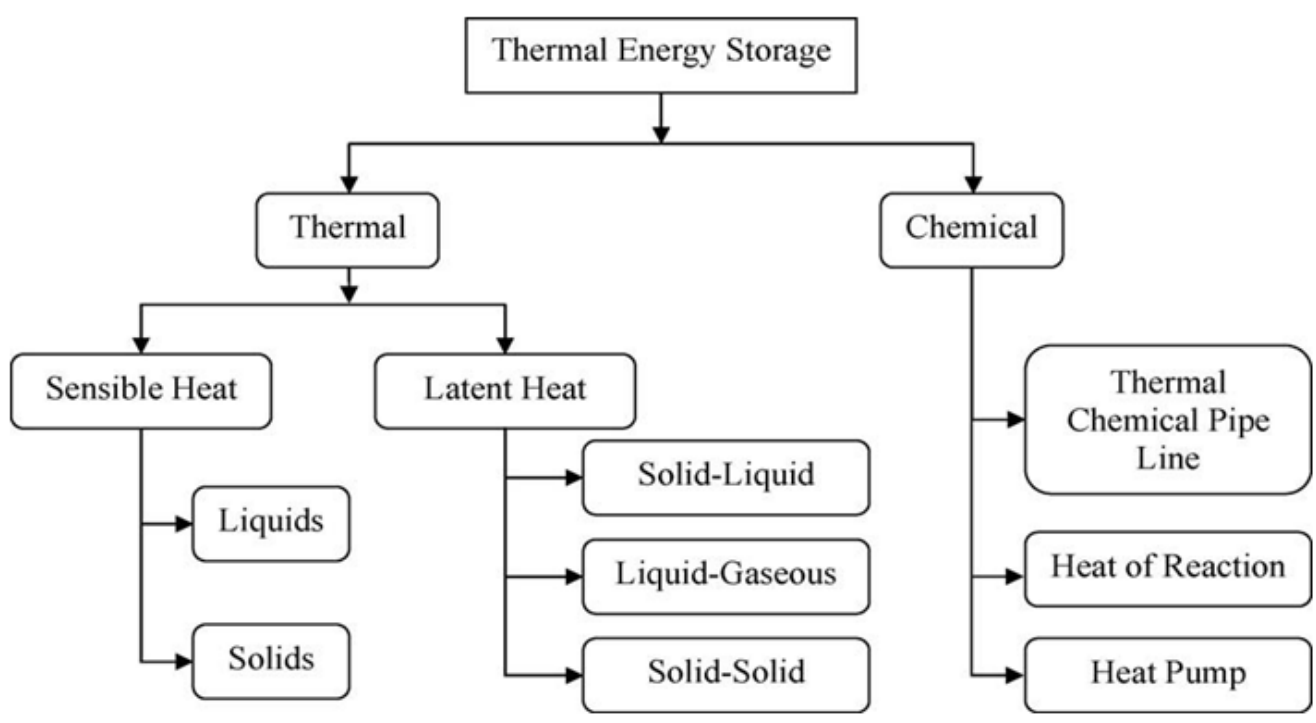

Fig 1: Different types of Thermal Storage of Solar Energy [5].

1. Sensible Heat Storage (SHS)

2. Latent Heat Storage (LHS)

3. Thermo-Chemical Heat Storage (TCHS)

\section{Sensible heat storage (SHS)}

Sensible Heat Storage (SHS) is the most economical and easiest form of energy storage. This only rises in temperature without undergoing any phase transition. The main drawback of sensible heat storage is that it required more space to store the heat because of the lower capacity of heat storage.

\section{Latent heat storage (LHS)}

Latent heat storage (LHS) stores thermal energy at the time of phase transition from solid to liquid or liquid to vapor in the form of latent heat of fusion and vaporization respectively. Latent Heat Storage (LHS) systems into the solar heating system are one of the hottest trends in solar thermal energy technology due to a large amount of energy that can be stored in a small volume with small temperature change. Latent heat storage can be used through solid-liquid, liquid-gas, solid-gas and solid-solid phase transformations. Among all the LHS systems solid-liquid and solid-solid are mainly used. Latent heat storage has a higher storage density as compared to sensible heat storage. Various types of Phase Change Material (PCM) are available of different characteristics as per suitability towards the various applications [6] PCM considered a promising material for transferring the heat at a constant temperature.

\section{Thermo-chemical heat storage (TCHS)}

The major drawback of a thermochemical storage system is the whole technology is very complex in nature.

\section{Phase change materials (PCMs)}

Amongst above thermal heat storage techniques, latent heat thermal energy storage is particularly more attractive to other due to its ability to provide high-energy storage density per unit mass and per unit volume in a more or less isothermal process, i.e. store heat at a constant temperature corresponding to the phase-transition temperature of PCM. Various types of PCMs studied and that can be used for integrating with the solar dryer in the appropriate temperature range. During sunshine hours, the maximum temperature within the drying chamber varies from $40{ }^{\circ} \mathrm{C}$ to $54{ }^{\circ} \mathrm{C}\left[{ }^{[7]}\right.$. One more advantage of latent heat storage material is, it supplies the energy at a constant temperature.

\section{Material and Methods}

This section deals with the materials and methodology adopted for experimentation at the Department of Renewable Energy Engineering, College of Technology and Engineering, Udaipur. The designed unit was developed at a departmental workshop, CTAE, Udaipur. The study area lies at $24^{\circ} 38^{\prime} \mathrm{N}$ latitude, $73^{\circ} 43^{\prime} \mathrm{E}$ - longitude and at an altitude of $582.5 \mathrm{~m}$ above mean sea level. The design parameters, fabrication techniques, instruments used, experimental procedure and technical analysis have been discussed in this chapter.

\section{Characteristics of PCM}

Barium hydroxide octahydrate material was used as a heat storage material and its properties are given as under.

$\begin{array}{cl}\text { S. No. } & \text { Parameters of PCM } \\ 1 & \text { Heat storage material } \\ 2 & \text { Melting point } \\ 3 & \text { Density } \\ 4 & \text { Latent heat } \\ 5 & \text { Specific heat } \\ 6 & \text { Molecular weight }\end{array}$

Characteristics
Barium hydroxide octahydrate
$78{ }^{\circ} \mathrm{C}$
$1937 \mathrm{~kg} / \mathrm{m} 3$
$265-280 \mathrm{~kJ} / \mathrm{kg}$
$1.817-3.1 \mathrm{~kJ} / \mathrm{kg} \mathrm{K}$
315.47

Techno-economic analysis of developed unit

The economic viability of any system can be calculated through an economic analysis of the system. For the success and commercialization of any new technology, it is essential to know whether the technology is economically viable or not. Therefore, an attempt was made to determine the economics of the PCM based unit for the solar tunnel dryer. The economics assessment of developed unit can be carried out based on net present value, benefit-cost ratio, internal rate of return and payback period ${ }^{[8]}$.

\section{Net present value (NPV)}

This is simply the present value of the cash flow stream. The difference between the present value of all future returns and the present money required to invest in the net present worth. The present values of the future return calculated through the use of a discount. Discounting is essentially a technique by which future benefits and cost streams can be reduced to their present worth. The process of finding the present worth of a 
future value is called discounting. The discounting rate is the interest rate assumed for discounting. The most straight forward discounted cash flow measure of project worth is the Net Present Value (NPV). The net present value can be computed by subtracting the total discounted present value of the cost stream from that of the benefit stream. The net present value of the developed system was calculated by the given formula,

$$
\begin{aligned}
& \frac{\mathrm{t}=\mathrm{n} \mathrm{B}_{\mathrm{t}}-\mathrm{C}_{\mathrm{t}}}{\mathrm{t}=1(1+\mathrm{i})^{\mathrm{t}}} \\
& \mathrm{NPV}=\sum
\end{aligned}
$$

\section{Where}

$\mathrm{Bt}=$ Benefit in each year,

$₹ \mathrm{t}=1,2,3 \ldots \ldots, \mathrm{n}$, years

$\mathrm{Ct}=$ Cost in each year, $₹$

$\mathrm{i}=$ Discount rate, $\%$

\section{Benefit-cost ratio}

This is the ratio obtained when the present worth of the benefit stream is divided by the present worth of the cost stream. The formal selection criterion for the benefit-cost ratio for the measure of project value was to accept projects for a benefit-cost ratio of 1 or greater. In practice, it is probably more common not to compute the benefit-cost ratio using gross cost and gross benefit, but rather to compare the present value of the net benefit with the present value of the investment cost plus the operation and maintenance cost. The ratio is computed by taking the present value of the gross benefit less associated cost and then comparing it with the present value of the project cost. The associated cost is the value of goods and services over and above those included in project costs needed to make the immediate products or services of the project available for use or sale. Project economic cost is the sum of installation costs, operation and maintenance cost and replacement costs.

The benefit-cost ratio of the developed system was calculated by the given formula,

$$
\text { Benefit }- \text { cost ratio }=\frac{\text { Total benefit }}{\text { Total cost }}
$$

\section{Internal Rate of Return (IRR)}

Another way of using the internal cash flow for measuring the worth of a project is to find the discount rate that makes the net present worth the incremental cash flow equal to zero. This discount rate is called the internal rate of return.

$$
\sum_{t=1}^{t=n} \frac{B_{t}-C_{t}}{t(1+i)}=0
$$

\section{Payback period (PP)}

The payback period is the length of time from the beginning of the project until the net value of the incremental production stream reaches the total amount of capital investment. It shows the length of time between cumulative net cash outflow recovered in the form of yearly net cash inflows.
The payback period (PP) of the developed system was calculated by the given formula,

$$
\text { Payback Period }=\frac{\text { Total Investment }}{\text { Total Profit }}
$$

\section{Result and Discussion}

Techno economics of the Heat Sink Unit for Solar Tunnel Dryer.

The techno economics analysis was carried out based on the assumptions given below. The detail costing is shown below. The cash flow (₹) for drying of potato slices with the use of PCM is presented. The benefit-cost ratio was found to be 1.33 with a payback period of 1.268 years. It can be inferred that the use of PCM is technically as well as economically feasible.

1. The life of a Heat Sink Unit with a Solar Tunnel Dryer is 10 years $(\mathrm{n})$.

2. The discount rate is assumed to be $10 \%$, (i).

3. The annual repair and maintenance cost is $2 \%$ of the total capital cost.

4. The cost of fresh potato is $20 \mathrm{Rs} / \mathrm{kg}$.

5. The cost of dried potato slices is $250 \mathrm{Rs} / \mathrm{kg}$.

6. Labor cost: one person can be involved to dry potato slices, so the labor charge for one person is considered as a $20 \mathrm{Rs} / \mathrm{h}$.

7. The STD and HSU can be operated 300 days in a year.

8. The cost of the system is Rs. 34200.

9. Fabrication cost is considered as $10 \%$ of the material cost.

10. Potato is available in the market throughout the year.

Table 1: Cash flow analysis for designed Heat Sink Unit for Solar Tunnel Dryer

\begin{tabular}{|c|c|c|}
\hline Production capacity & $\mathbf{1 . 3 5}$ & Kg/day (batch) \\
\hline Operating days per year & 300 & days \\
\hline Raw material & Potato Slice & \\
\hline Dried potato slices & 405 & Kg/year \\
\hline \multicolumn{2}{|c|}{ Investments } \\
\hline The cost of HSU & 24200 & Rs \\
\hline The cost of STD & 8000 & Rs \\
\hline Total investment (A) & 32200 & Rs \\
\hline Cost & & \\
\hline Manpower @ 20 Rs/h for one labor & 12000 & Rs/year \\
\hline Repair and maintenance @ 2\% of (A) & 644 & Rs/year \\
\hline Discount rate @ 10\% of (A) & 3220 & Rs/year \\
\hline Cost of raw material @ 20 Rs/h & 60000 & Rs/year \\
\hline Cost of production (B) & 75864 & Rs/year \\
\hline Profitability & \\
\hline $\begin{array}{c}\text { Net selling price of dried potato slices } \\
\text { is 250 Rs/kg. (C) }\end{array}$ & 101,250 & Rs/year \\
\hline Net annual saving D = C - B & 25386 & Rs/year \\
\hline NPW (Rs) & 123785 & Rs. \\
\hline Benefit cost ratio = C/B & 1.33 & \\
\hline Payback period = A/D & 1.268 & Year \\
\hline
\end{tabular}

Table 2: Economic Analysis of HSU for STD

\begin{tabular}{|c|c|c|}
\hline S. No. & Economic indicator & Value \\
\hline 1. & Net Present Worth (NPW) & 123785.98 ₹ \\
\hline 2. & Benefit-cost ratio & 1.33 \\
\hline 3. & Payback period & 1.268 Year \\
\hline 4. & Internal rate of return & $62 \%$ \\
\hline
\end{tabular}




\section{Net present worth (NPW)}

The NPW for the system was calculated based on present investment and the interest rate considered for the system and the profit in each year. The life of the system was considered for 10 years thus the NPW for the HSU with STD was Rs. 123785.98 .

\section{References}

1. Kothari S, Panwar NL, Chaudhri S. Performance evaluation of exhaust air recirculation system of mixed mode solar dryer for drying of onion flakes. International Journal of Renewable Energy Technology 2009;1:29-41.

2. Ghasemkhani H, Keyhani A, Aghbashlo M, Rafiee S, Mujumdar AS. Improving exergetic performance parameters of a rotating-tray air dryer via a simple heat exchanger. Applied Thermal Engineering 2016;94:13-23.

3. Sain P, Songara V, Karir R, Balan N. Natural convection type solar dryer with latent heat storage. Renewable Energy and Sustainable Energy 2013;5:9-14.

4. Singh PL, Deshpandey SD, Jena PC. Thermal performance of packed bed heat storage system for solar air heaters. Energy for Sustainable Development 2015;29:112-117.

5. Elouali A, Kousksou T, Rhafiki T, Hamdaoui S, Mahdaoui M, Allouhi A, et al. Physical models for packed bed: Sensible heat storage systems. Journal of Energy Storage 2019;23:69-78.

6. Sharma SD, Iwata T, Sagara K. Thermal performance of box type solar cooker: a study in Japan climate. Journal of Japan Solar Energy Society 2004;30:49-54.

7. Devahastin S, Pitaksuriyarat S. Use of latent heat storage to conserve energy during drying and its effect on drying kinetics of a food product. Applied thermal engineering 2006;26(14-15):1705-1713.

8. Panwar NL, Kothari S, Kaushik SC. Cost-benefit and systems analysis of passively ventilated solar greenhouses for food production in arid and semi-arid regions. Environment Systems and Decisions 2014;34:160-167. 